\title{
Cytochrome P450
}

National Cancer Institute

\section{Source}

National Cancer Institute. Cytochrome P450. NCI Thesaurus. Code C16484.

A family of cytochromes that are involved in electron transport and oxidative metabolism

of drugs and other bioactive molecules. When the catalytic heme is reduced the absorbance peak for this protein occurs at $450 \mathrm{~nm}$. 